\title{
SOCIAL RESPONSIBILITY AND CITIZENSHIP IN STRATEGIC MANAGEMENT
}

\author{
Müberra YÜKSEL \\ Kadir Has University, Turkey
}

\begin{abstract}
Recently, organizational citizenship behavior such as sharing knowledge and complying with procedures has become increasingly important as a source of competitive advantage. While encouraging employees to act in line with the organizational goals both in terms of result and competencies, organizations emphasize human resources and knowledge management so that integration for innovative solutions to business problems may be possible in the globalizing economy. Meanwhile, compliance with the norms of stakeholders concerning issues such as consumer and employee rights and environmental safety in developing countries are often the top issues of corporate citizenship.
\end{abstract}

Following Matten \& Crane, I have regarded corporate citizenship in a broad sense which emphasizes the role of a corporation in administering individual citizenship rights that distinguished it from corporate social responsibility. Such a definition reframes the citizenship by acknowledging that the corporation administers certain aspects of citizenship for other constituencies. These include traditional stakeholders, such as employees, customers, or shareholders, along with wider constituencies with no direct transactional relationship to the selected organization.

Most studies on organizational citizenship are either focusing on personality aspects of employees or on organizational culture. This study aims at contributing to the literature by examining this important and diffuse issue empirically and paves the way for clarifying the conceptualization of organizational citizenship attitudes and behaviors. This research is driven by the supposition that people choose to engage in authentic organizational citizenship behavior rarely since most employees feel insecure about their jobs and positions and consequently their motives may either have hidden agenda for personal gain by impressing others or looking good to their superiors.
Building upon prior studies on citizenship in Turkey, I aim at showing the perception of employees about organizational citizenship in a developing country framework empirically. I will analyze the perceptions on organizational citizenship based on results of the survey of employees in the finance sector in Istanbul, Turkey. My first assumption is that citizenship has to increase the awareness of their employees as internal customers and investors as internal stakeholders and then spread it out to external stakeholders. Consequently, my second assumption is organizational citizenship precedes corporate citizenship. Thus, an effective human resource management that enables and cascades down corporate values and priorities is presumed to be a precondition for employees. I expect that identification will be high particularly among employees who believe both in the significance of their future role and competencies in terms of their career and their corporate status within the selected joint-venture bank.

I have aimed at analyzing identification mainly from two perspectives: the social identity and organizational impression management theories. There are generally two sets of psychological dimensions: normative and perceptual. The first aspect is about social developments and commitments particularly at work that provide expectations and limitations, the latter is about personal cognitive processes and perceptions that help to interpret and organize information, particularly on the image of organization as well as employees' self concept. Drawing upon social identity theory, I argue that the salience of organizational identification leads to greater commitment and organizational citizenship behavior.

Organizations set categories defining the prototypical attributes associated with organizational identification and citizenship that become the salient dimension in employee's social identities through sanctions a well as incentives. The status associated with the firm influences employee's perceptions of self-esteem and 
deference. While the first reflects assessments of the status of the organization and adequacy of its procedures, the latter shows how an employee is judged and recognized by others, trust and organizational justice. Such evaluations influence the extent to which employees are engaged in their work and/or company and develop their competencies; consequently, they may become first "organizational" and then "corporate" citizens or vica versa.

In this vein, an empirical research in this field of corporate communications may pave the way for a better understanding on employees' attitudes on citizenship and its impact on their organizational identification as well as their alignment with organizational codes of conduct. Organizational citizenship may facilitate organizational identification not only because it enhances the perceived organizational identity, but also because it is contributing to an affirmative external image of the firm.

On the whole, in this paper I argue that organizationoriented behavior is linked to the role organizations play in defining employee's social identities, given that the organization follows the ground rules and codes of conduct that are cascaded down through organizational culture. I aim at explaining the intangible features of commitment to work as well as to organizations in a particular case study with a social identity and work values focus. The normative aspects of organizational citizenship emphasizing complying with procedures, on one side and the perceptional measures concerning achievement, appreciation and procedural justice on the other are expected to be the main determinants of organizational belonging and citizenship.

Key Words: Organizational Citizenship, Corporate Citizenship, Impression and Social Identity.

\section{INTRODUCTION}

In the globalization process corporations have been gaining influence, often without engaging in the improvement of the common good for all stakeholders. Along with the affirmative impact of globalization, the negative effects of foreign investment to various stakeholders such as the environmental damage, financial market instabilities, exploitation of both employees and consumers, cultural hegemony, erosion of local culture and community have increased the debates on the accountability of foreign corporations and joint ventures (Matten, D \& Crane, A 2004) It is no longer sufficient for corporations to behave fine in developed countries, while violating basic norms of worker, consumer, environmental and community protection elsewhere. Corporate Citizenship (CC) functions as a new way of presenting existing concepts of Corporate Social Responsibility (CSR) but applied to a wider and further set of issues (Kalkan \& Yüksel; 2007).

Corporate citizenship focuses on corporate responsibilities; however, CC comprises of individual, social, civil and political citizenship rights and obligations that are conventionally granted and are transnational most of which are protected by national polities and governments (Matten \& Crane, 2005: 166). There are numerous conceptual and operational definitions of corporate citizenship; we have employed Maignan and Ferrel's (2005) definition which emphasizes stakeholder management theory in our preliminary evaluations through in depth interviews with managers in our case study. We emphasized the legal, economic, and ethical along with the most significant discretionary responsibilities imposed upon the financial institutions by stakeholders such as employees, shareholders, business partners, suppliers, customers, competitors, legal and public authorities and local communities. We have checked the documents related with corporate citizenship and then decided that the most promising stakeholders are traditional internal ones, i.e., the shareholders, partners and employees.

The transnational conception of globalization proposes the existence of a global system comprised of multinational corporations or transstate enterprises. MNCs are the basic units of analysis and building blocks of this process. They operate cross-state boundaries both in their home and host countries. Analytically, they practice in four spheres, the economic, the legal, the political, and the culturalsocial. They are often globalizing in terms of foreign investment, benchmarking and best practices, global vision and consumer citizenship along with corporate citizenship. A major goal is to provide a regulatory framework to constrain the operation of transnational forces of business so that the protection of the global commons, the erection of a global safety net for the vulnerable constituencies, and the like. Meanwhile, a major shift on the aspirational side of citizenship involves a movement from an emphasis on space to an emphasis on time. Such a shift corresponds to the exhaustion of government as a sole source of innovative problem-solving with respect to fundamental social welfare concerns. It also reflects the impact of economic globalization, and the current absence of countervailing political possibilities, yet the need for 
citizenship behavior in a case study within the Turkish sociocultural context.

I think that in a country like Turkey where "social desirability" is high and people underline social belonging and perception of others, employees often play the role of "actors" or "soldiers". The former acts and looks as if and often prefers behind-the-scenes activities and the latter obeys and complies to the procedures out of duty without taking full responsibility or internalizing the values of citizenship. We suggest and hypothesize that 'the good corporate citizen' may align in congruence with the expected values of the organization and workgroups and commit himself or herself both to work and organization through empowerment and trust.

Allen and Meyer (1990) studied and operationalized organizational commitment as a multidimensional construct comprised of push and pull factors. The push factor is continuance commitment which focuses on one's awareness of the sunk or opportunity costs associated with leaving the present organization and the job. I have only considered the two pull factors: emotional attachment and normative commitment since the first is about participation in and identification with the organization, while the other is about the responsibilities or obligations of employees to the organization based on norms and values (See Exhibit 1).

One reason as to why I have omitted the push factors including continuance commitment criteria is based on the emphasis of affirmative psychological aspects in our literature review. These are two sets of psychological dimensions: normative and perceptual. The first aspect is about social developments and commitments particularly at work that provide expectations, the latter is about personal cognitive and affective processes that help to interpret and organize information, particularly information bearing on the image and reputation of organization as well as the employee's self concept.

Empirical research done by both professional researchers and academicians' findings about Turkish employee behavior also support that pull factors have more weight on attracting, retaining employees (AC Nielsen, 2001 and 2006) and the normative and affective commitment variables are related with organizational commitment as well as citizenship behavior (Çetin, $2004 \&$ Balay, 2000). As for corporate social responsibility activities, while the public at large gives priority to education and training projects, and then to health, environment and violence within the family, the business world also emphasizes education and goes on with increasing the awareness of social morality, social security and health as the other top issues. On the whole, both corporate citizenship and/or organizational behavior is conceptually confusing since it is related with theoretical concepts such as transformational leadership, organizational culture, organizational commitment, empowerment, procedural justice, motivation, job satisfaction, personality, conflict and team management. However, I have mainly used Organ's operationalized construct for this paper (See Exhibit 2).

\section{EXHIBIT 1.}

\section{MODEL 1: Organizational Commitment}

(1) Normative commitment items

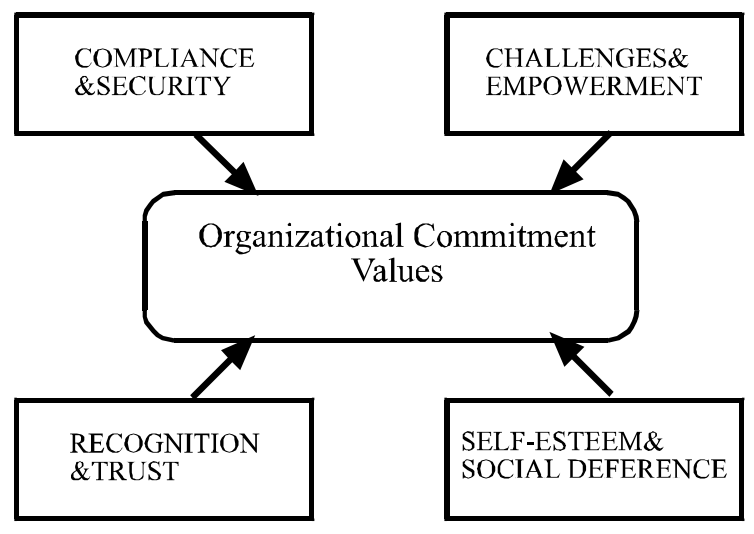

(2) Affective commitment items \& Social Identity items CRITERIA -Based on Allen\&Meyer's Affective\&Normative commitment items adopted to Social Identity values

\section{EXHIBIT 2.}

\section{Model 2: Organizational Citizenship}

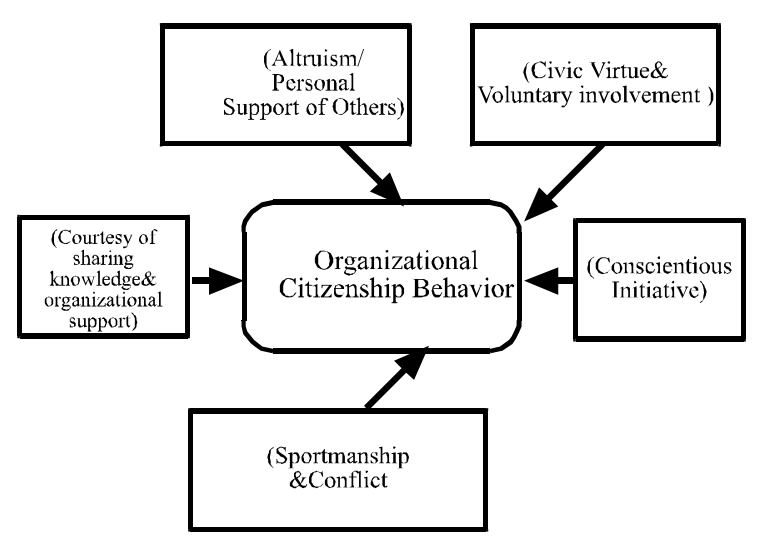

Criteria - Based on Organ's operationalized items 


\section{METHODOLOGY \& FINDINGS}

Despite the fact that there is no single, commonly agreed definition, indicators and metrics of $\mathrm{CC}$, in the study I have tried to develop a tool based on the Maignan (2005) CC definition for the evaluation of corporate citizenship activities in the foreign companies. Combining CSR and Stakeholder management theory, Maignen defines it as the extent to which businesses assume the economic, legal, ethical and discretionary responsibilities imposed on them by their various stakeholders including employees, shareholders, business partners and suppliers, customers, competitors, public authorities and NGOs representing local communities, environment. I have first conducted in-depth interviews with top and middle managers to determine the $\mathrm{CC}$ practices and codes of conduct. Exhibition 3 presents the 12 elements of CC as the sources of guidance and checklist used in the research. Some corporate citizenship elements are established from CSR indicators (Welford; 2005), some of them selected through consideration of many voluntary or regulatory international, regional or local standards, codes of conducts, initiatives, declarations and conventions which represent the source and further information about each element and they are provided in the second column.

By and large, elements of employee rights within the company's own operations all commonly found as policies in the selected bank. This can probably be explained by the fact that these policies are required by Turkish law as well as financial reporting to the Banking Audit Commission, Stock Exchange Commission and the like. The policies about the protection of human rights within the company's own operations, prevention on child labor and forced labor in the workplace is found important, while policies on profit-sharing and share ownership schemes are not introduced yet. The interviewed managers mentioned policies on non-discrimination in the workplace and responsible recruitment practices and equal opportunities statements and implementation plans consisting equal pay and career prospects for women. The rate about working standards like statement on normal working hours, maximum overtime and fair wage structures is not that clear, though. Staff development, in-house education and vocational training, lifelong learning, empowerment of employees, better information flow throughout the company is also rather high.

When it comes to an examination of transparency and accountability there are written policies. This might come from the fact that corporate accountability often refers to legal obligations on banks imposed by governments such as regular reporting for auditing to make management accountable to shareholders in the narrow sense. The moral obligations towards all stakeholders about any transaction are generally overlooked. Although policies and procedures concerning codes of conduct (including bribery and corruption) along with core competencies of employees and relevant training programs are highlighted, training programs to promote corporate citizenship has not commenced yet.

Most of the policies concerning employee rights including profit-sharing schemes are adequately implemented. Most of these policies are required by Turkish Labor Law and finance sector has gone through a restructuring and auditing after a sequence of crises. Still, awareness of OECD Guidelines, ILO convention, EU Green Paper as sources of guiding principles was relatively higher than anticipated, probably due to the transformation process (See BCG, 2005 Survey on Corporative Governance for a general picture of Turkey).

\section{EXHIBITION 3.}

\begin{tabular}{|c|c|c|}
\hline $\begin{array}{l}\mathbf{C} \\
\mathbf{H} \\
\mathbf{E} \\
\mathbf{C} \\
\mathbf{K}\end{array}$ & $\begin{array}{l}\text { Our company operating in } \\
\text { Turkey has written } \\
\text { policies, procedures and } \\
\text { practices in the area stated } \\
\text { below }\end{array}$ & $\begin{array}{l}\text { Source of Guidance } \\
\text { International standards, codes } \\
\text { of conducts, initiatives, } \\
\text { declarations and conventions } \\
\text { principles ext. }\end{array}$ \\
\hline \multirow[t]{3}{*}{ list } & INTERNAL ASPECTS & \\
\hline & A) Employee & \\
\hline & $\begin{array}{l}\text { The protection of human } \\
\text { rights within the } \\
\text { company's own } \\
\text { operations }\end{array}$ & $\begin{array}{l}\text { UN Universal Declaration of } \\
\text { Human Rights, } \\
\text { UN Global Compact, } \\
\text { SA 8000, Turkish law }\end{array}$ \\
\hline & $\begin{array}{l}\text { Prevention on child labor } \\
\text { and forced labor in the } \\
\text { workplace }\end{array}$ & $\begin{array}{l}\text { UN Universal Declaration of } \\
\text { Human Rights, } \\
\text { SA 8000, CEPAA, } \\
\text { Turkish law }\end{array}$ \\
\hline & $\begin{array}{l}\text { Profit-sharing and share } \\
\text { ownership schemes }\end{array}$ & EU Green Paper \\
\hline & $\begin{array}{l}\text { Non-discrimination in the } \\
\text { workplace \& during } \\
\text { recruitment practices, etc. }\end{array}$ & $\begin{array}{l}\text { ILO Convention, } \\
\text { SA } 8000 \\
\text { Global Compact, } \\
\text { CEPAA, Turkish law }\end{array}$ \\
\hline & $\begin{array}{l}\text { Equal opportunities } \\
\text { statements and } \\
\text { implementation plans } \\
\text { equal pay and career } \\
\text { prospects for women, etc. }\end{array}$ & $\begin{array}{l}\text { Convention } 100,110 \text { and } 111 \text {, } \\
\text { SA } 8000 \text {, CEPAA } \\
\text { Turkish law }\end{array}$ \\
\hline & $\begin{array}{l}\text { Statement on normal } \\
\text { working hours, maximum } \\
\text { overtime and fair wage } \\
\text { structures }\end{array}$ & $\begin{array}{l}\text { ILO Conventions } 1,30 \\
\text { and } 47 \text {, } \\
\text { Global Compact,SA } 8000 \\
\text { CEPAA, Turkish law }\end{array}$ \\
\hline & $\begin{array}{l}\text { The right of freedom of } \\
\text { association, collective } \\
\text { bargaining and } \\
\text { complaints procedures }\end{array}$ & $\begin{array}{l}\text { ILO Convention } 98 \\
\text { OECD Guidelines } \\
\text { CEPAA, Turkish law }\end{array}$ \\
\hline
\end{tabular}


alternatives with normative content, both to moderate the cruel effects of the global market and to give impetus to reformist perspectives (Falk 1993).

\section{The Relation of Competitive Strategy, Corporate Governance and Social Responsibility}

While corporate governance as a construct is quite new to our daily business language, it is an allembracing concept including strategy and performance of the organization along with managerial control and accountability. Effective business processes and strategies result in higher business performance. Yet, competent behavior is the enabler that makes both strategy and process work. Effective performance demands appropriately effective behavior and priorities. In other words, efficient organizational change and corporate governance certainly requires effective change in corporate culture and values. That is easy to say but rather difficult to do since defining, understanding, observing patterns of behavior and measuring values are all challenging issues. Still, good corporate governance is only achieved if strategic policies as well as processes at work are in line with the values at work. Otherwise, improvements or implementations are either incomplete or they are not sustainable due to misalignment of business ethics. For instance, without a certain degree of accountability and transparency to stakeholders, meaningful constructive feedback, interaction, any kind of evaluation or building trust would not be possible.

The shareholder-centered model used in America includes more dispersed ownership, strong legal protection for shareholders and indifference to other stakeholders. The hybrid model combines features from both the shareholder and stakeholder models, defined by a less clear separation between dispersed ownership and managerial control. In other words, stakeholders have more influence over the operation of the company. Turkish corporations just like French companies are often criticized for a governance approach that involves an intricate network of public agencies, large firms and banks. Is globalization more about leveraging differences in an increasingly borderless world or is it about convergent codes of conduct. There is an important connection between corporate governance, the competitive strategy of firms and its sustainability (Bay \& Küskü, 2006).

With increasing globalization, corporations and banks -domestic or foreign- have been growing with little or no concern for stakeholder interest and their common good. After numerous scandals questioning the accountability of multinational operations of service and manufacturing companies, lately, the norms of stakeholders concerning issues such as environment, consumer or employee rights are expected to be strictly followed in developed countries. A global ranking report indicates that even the world's largest companies have a weak record on corporate governance and stakeholder management and their corporate social responsibility (FT, June 23rd 2004). Likewise, the situation is not hopeful in Turkey (BCG; 2005). That is one reason I wanted to probe into this topic to be able to determine where the bank in this paper is standing.

Unfortunately, in developing countries, domestic as well as foreign companies/banks often adhere to these standards in a limited way or violate some of these norms. Although there are lots of corporate social responsibility projects, most of them are not aligned or integrated with corporate strategy or culture. Hence, corporate citizenship captures more precisely what is framed by corporate social responsibility in a limited or extended way (Carroll; 1998). For the sake of brevity and confidentiality, however, I have limited my inquiry to employees' perceptions and focused on organizational citizenship and individual values rather than those of corporate citizenship.

In this paper I argue that organization-oriented behavior is linked to the role organizations play in defining employee's social identities, given that the organization follows the ground rules and codes of conduct that are cascaded down through organizational culture. I aim at explaining the intangible features of organizational identification in a particular case study with a social identity and citizenship focus- mostly organizational rather than corporate citizenship. Normative aspects of citizenship emphasizing complying with procedures, on one side and the perceptional and affirmative measures concerning achievement and appreciation and procedural justice on the other are expected to be the main determinants of organizational belonging and organizational citizenship.

\section{A Brief Overview of the Banking Sector in Turkey}

Turkey has faced high inflation rate in the last three decades. High inflation along with public deficits ended up in heavy public borrowing. In this period, the banks in Turkey acted as an intermediary for public borrowing instead of focusing on banking functions. 
Meanwhile, foreign capital investments have increased as a consequence of high real interest rates. The interest rate fluctuations coupled with imbalanced asset-liability structure of the banking sector culminated at a volatile economy and led to banking crises, in 1994 and 2001. In order to regain the trust of people towards banking sector, the government provided deposit guaranty for the deposits in banks until the end of 2004.

Banking crises revealed the fact that banks should have early warning systems to detect inefficiencies in all kinds of transactions. The lessons, which can be drawn from prior crises, are acknowledgement of the need for human resources planning, a performance and learning focused on organizational culture and human resources. The bank in this research is a large scale Turkish Bank operating in many foreign countries. It was established in late 1980s in Istanbul. In the initial years, it has focused on institutional banking with limited number of branches. After the first banking crisis in Turkey it changed its focus towards retail banking to be able to widen its service range and to diversify its risks. It has hundreds of branches today and operates not only in institutional and retail banking but also in small and medium sized enterprises' banking with approximately 10000 employees. The bank has acquired its Quality License in 1998 and upgraded it to ISO 9000:2000 version in 2003 and institutionalized total quality management. Recently, it has merged with a large foreign bank from EU and it is now going through a cultural transformation. Hence, I checked first the regulatory frameworks rather than informal standards, core values by interviewing mostly with the top level human resource director since formal frameworks shapes the pattern of business behavior of all stakeholders. Later on, I limited my focus mainly to employees as the unit of analysis.

Most banks that are getting ready for a change initiative know that they need to assess their business needs, audit their existing technology solutions and identify the gaps that need to be addressed. What many fail to realize, however, is that such corporate governance, corporate citizenship and stakeholder management systems have strong cultural components that need to be managed and organized as well. Unfortunately cultural due diligence is often either overlooked or done very rapidly in most mergers and acquisitions or joint-ventures in Turkey. There are at least two perspectives that must be considered to determine the cultural fitness of any company or a bank:

$\checkmark$ The top management has to take an active role in the project to be able to change conventional ways of doing things, and

$\checkmark$ They need to be ready to communicate frankly and share more information with more employees so that they will all be involved.

\section{Conceptual Framework for Citizenship}

After employees as the most significant internal stakeholder and the internal customer are consumers. Consumers are clearly one of the most important external stakeholders for any organization, since they are also the external customers. Further, without the support of customers of some sort, such as through the demand for or purchase of goods and services, most organizations would unlikely survive for very long. (Crane \& Matten, 2004). Therefore the role of the consumers in shaping the social and environmental impact of corporations become evermore critical. Consumers' support of corporate citizenship is very important as Maignen \& Ferrell (2001) point out that the corporate citizenship is likely to be acknowledged by businesses as a worthwhile investment if its activities clearly supported by consumers through their evaluation of purchasing alternatives. Based on a survey of managers Maignan, Ferrell \& Hult (1999) establish a positive relationship between proactive citizenship and customer loyalty.

Dimensions of corporate citizenship and types of initiatives generate consumer awareness. Because of the interdependence between corporate and consumer citizenship, businesses could learn about the most desirable means of communicating corporate citizenship. According to Maignan and Ferrell (2001) there are two dimensions of corporate citizenship communications: intensity and trust in the source likely to influence consumers' evaluations of corporate citizenship and impact on his/her attitudes and behaviors. One could assume that up to a certain point, the more consumers are reminded of the corporate citizenship of a given firm, the more likely they are to integrate these initiatives in their purchasing decisions. However, when corporate citizenship is promoted extremely heavily, consumers may perceive that it is mainly used as a promotional appeal, and may become suspicious about the intent of the firm. This reasoning entails that consumer's trust in the source of the corporate citizenship communications is also likely to affect the relationship between evaluations of corporate citizenship and consumer behavior. Information regarding the activities undertaken by an organization to meet one or several of its social responsibilities may influence consumer 


\begin{tabular}{|l|l|l|}
\hline $\begin{array}{l}\text { Staff development, } \\
\text { in-house education and } \\
\text { vocational training, } \\
\text { lifelong learning, } \\
\text { empowerment of } \\
\text { employees, better } \\
\text { information flow } \\
\text { throughout the company }\end{array}$ & $\begin{array}{l}\text { UNESCO Project on } \\
\text { Technical and Vocational } \\
\text { Education (UNEVOC) } \\
\text { EU Green Paper, OECD } \\
\text { Guidelines }\end{array}$ \\
\hline B) Investors & $\begin{array}{l}\text { Health and safety at work } \\
\text { beyond the legislation }\end{array}$ & $\begin{array}{l}\text { European Agency for } \\
\text { Safety and Health at Work }\end{array}$ \\
\hline $\begin{array}{l}\text { Maximizing shareholder } \\
\text { value, focus on returns } \\
\text { firstly }\end{array}$ & $\begin{array}{l}\text { Classical Corporate } \\
\text { Governance }\end{array}$ \\
\hline $\begin{array}{l}\text { Publishing a 'triple bottom } \\
\text { line' in the annual reports } \\
\text { to shareholders that } \\
\text { measures performance } \\
\text { against economic, } \\
\text { environmental and social } \\
\text { criteria }\end{array}$ & $\begin{array}{l}\text { Global Reporting } \\
\text { Initiative, } \\
\text { Corporate Governance, } \\
\text { SVN's Standards }\end{array}$ \\
\hline $\begin{array}{l}\text { Commitment to take } \\
\text { place on responsible } \\
\text { investment (SRI) }\end{array}$ & $\begin{array}{l}\text { IMKB Corporate } \\
\text { Governance Index, Dow } \\
\text { Iones' sustainability }\end{array}$ \\
\hline
\end{tabular}

I have employed in-depth interviews for both checking corporate obligations, codes of conduct and core competencies. Then I conducted two surveys at the same time to analyze the relationship between organizational commitment values and citizenship behavior of employees and managers with a total response of 150 . The demographic distribution of the sample with respect to position and gender are as shown below:

POSITION
\begin{tabular}{|l|l|r|r|r|r|}
\hline & & Frequency & Percent & $\begin{array}{r}\text { Valid } \\
\text { Percent }\end{array}$ & $\begin{array}{r}\text { Cumulative } \\
\text { Percent }\end{array}$ \\
\hline Valid & manager & 81 & 54 & 54 & 54 \\
\hline & employec & 69 & 46 & 46 & 100 \\
\hline & Total & 150 & 1000 & 100 & \\
\hline
\end{tabular}

GENDER
\begin{tabular}{|l|l|r|r|r|r|}
\hline & & Frequency & Percent & $\begin{array}{r}\text { Valid } \\
\text { Percent }\end{array}$ & $\begin{array}{r}\text { Cumulative } \\
\text { Percent }\end{array}$ \\
\hline Valid & male & 77 & 51.3 & 51.3 & 51.3 \\
\hline & female & 73 & 48.7 & 48.7 & 100.0 \\
\hline & Total & 150 & 100.0 & 100.0 & \\
\hline
\end{tabular}

The questionnaire I have employed comprised of 56 items; only eight comprised of organizational commitment items and the remaining 48 items are about organizational citizenship items of Model 2. I used Allen \& Meyer's organizational commitment construct based on affective, continuance and normative components (1991 \& 1996); however I omitted the continuance commitment. I have used confirmatory factor analysis in the combined model in which I have also included social identity values; most of which were in congruence with affective commitment items. I have probed into two major axes of social identity: pride about organizational status reflects the rule complying behavior of employees, whereas the reputation, respect or deference is about an employees' position in the organization and is the social aspect of identity. I have found significant difference among employees' versus managers' perceptions except for the challenge and empowerment criteria (See Table 1 in Appendices).

First, the comparison of ideal values and actual individual values give some significant results since the comparison is made within 150 participants and this sample number is enough for a statistical result. Most of the ideal values' means are higher than the means of actual ones. This means that, Turkish employees want more than they get about their values in their organizations. I have employed t-test statistics and I regarded the means of responses of both groups are equal as the null hypothesis. Only three of actual dimensions' means are higher than the ideal ones. Two of the pairs are about pride/bureaucratic respect, that is, employees are neither pleased to support traditional ways and to work according to agreed standards and comply with them nor do they prefer showing social respect and deference to other based on status. The last pair is about stability and trust which reveals that employees both lack trust and have little faith in the stability of the organization along with the security of their positions (See Table 1 in Appendices).

\section{EXHIBIT 4.}

The Organization\&Employee Relations (Human Resource Management from an Ethical Standpoint)

\section{EMPLOYEE RIGHTS AS STAKEHOLDERS (from a corporate citizenship standpoint)}

Right to Freedom from Discrimination

(e.g., equal opportunities, reverse discrimination)

Right to Privacy

(e.g.,work-life balance, data protection and electronic privacy)

Right to Due Process

(e.g., promotion, firing)

Right to Participation

(e.g., decision process)

Right to Safe \& Healthy Working Conditions

Right to Fair Wages

(e.g., appropriate pay)

Right to Freedom of Conscience \& Speech

Right to Work

(e.g., fair treatment in the interview or job security)

\section{EMPLOYEE DUTIES}

Duty to Comply with the Labor Contract

Duty to Comply with the Law

Duty to respect the Employer's Property 


\section{CONCLUDING REMARKS FOR DISCUSSION}

In today's competitive economy, employee commitment and their corporate citizenship behavior such as sharing knowledge for courtesy, alignment of their goals with those of the organization, complying with procedures becomes increasingly important as a source of competitive advantage. Organizations emphasize human resources and knowledge management and encourage their employees to act in line with the corporate goals both in terms of result and competencies so that integration for innovative solutions to business problems may be possible in globalizing economy.

As it has been argued that today's paradigm is of the conscientious consumer citizen who "civilizes the market economy" and contributes to sustainability. (Thoreseen, 2003). Sternberg (1998) puts it, if individuals have views as to how business should be conducted, they should ensure that their individual choices accurately reflect those views. When each potential stakeholder otherwise known as every member of society acts conscientiously in his personal capacity, and strategically bestows or withholds its economic support on the basis of its moral values, then the operation of market forces will automatically lead business to reflect those values.

Business ethics is concerned both with developing codes, concepts, and practices of acceptable business behavior and with carrying out these practices in all business dealings with its various stakeholders. But for some corporations, social and environmental performances are seen as a source of competitive advantage or a condition to be competitive. Many evidence shows social responsibility efforts are simply PR exercises. Classical corporate governance focusing profit firstly still remains to be prominent. As a conclusion in the overall citizenship model responsiveness, transparency and trust between producer and consumer and employee may be stimulated by compulsory regulations coupled with resonant ethics and mechanisms like corporate governance systems that provide all stakeholders to observe companies and seek for accountability.

One could argue, however that regulatory frameworks shape business behavior more than ethical principles and practices. (Employee, Competition and taxation etc.) In this connection, there is a need to distinguish voluntary from regulatory concepts. It could be argued that regulation provide stakeholders with the necessary rules to correct companies' failure, a requirement for the advancement of the common good. Laws and regulations however frequently reflect minimums therefore, the laws may not be at a level or standard that is truly needed to protect various stakeholder groups.

By and large, economic conditions in Turkey, forces all firms to be efficient and effective in internal processes. The rising competition among Turkish Banks forces them to emphasize employee and customer commitment as well as citizenship. Despite recent interest in corporate or organizational citizenship behavior, we do not have enough understanding of what citizenship means, especially with respect individual employee's values, motives and norms. Most studies are either focusing on personality aspects of employees or organizational culture. This study aims at contributing to the literature by examining this important and diffuse issue empirically and paves the way for clarifying the conceptualization of organizational citizenship behaviors. This study was driven by the assumption that people choose to engage in authentic organizational citizenship behaviors rarely since most employees feel insecure about their jobs and positions and consequently their motives may either have hidden agenda for personal gain by impressing others.

The findings demonstrated that employees engage in citizenship behaviors stemming from different motives such as organization concern motives, prosocial values, and workgroup coordination motives, all of which are based on social identity values. Yet, the clarity of operationalized concept is as difficult as the theoretical construct. Although the results did not seem to reveal a strong relationship between impression management motives and citizenship behaviors, still it is plausible for individuals to act as if they are committed to their work or organization and act as organizational citizens either to show off their capabilities or to look good. Future research needs to further investigate the possible relationship.

This study has various limitations and calls for future studies. First, it is a case study. Second, the data are collected at one point in time, which limits the causal inferences that we can draw. Although our findings reveal that employees engage in citizenship behaviors stemming from different motives particularly based on social identity values rather than impression management motives, still it is possible for individuals to act as if they are identified with their organization and act as corporate citizens either to show off their capabilities or to look good. 
decisions only if individuals judge this information as objective and trustworthy. According to Willmott (2003) corporate citizenship (as well as transparency and, to a lesser extent, communications activity) help to increase trust in the company.

Corporate citizenship communications increase the awareness and social involvement of the consumer citizens. Corporate citizenship communications refer to the promotional instruments produced by the company or by the media that depict the initiatives undertaken by the firm to meet its economic, legal, ethical, and discretionary responsibilities. Lately, the impact of corporate citizenship is beginning to be regarded as community issues such as human rights and labor practices to health care and the environment. Corporations have started to organize their community and consumer involvement activities to attain the most strategic benefit and competitive advantage to the firm in the long term by leveraging on corporate citizenship.

\section{LITERATURE REVIEW}

\section{Organizational/ Corporate Culture}

Prior research on outcomes of organizational or corporate culture indicates that culture plays at least four important roles in organizations. First, culture forms a collective identity that helps its members associate themselves with their organization's policies and mission, and feel themselves a part of it (Hofstedte, 1998: 477-492). Second, organizational culture prescribes norms of acceptable and unacceptable behavior, making it clear for employees what they should say or do in a given situation. Third, these norms help employees work together to meet customers' needs and respond to external pressures. Fourth, culture provides structure and control without relying on an authoritative management style that can lessen motivation and creativity ( 0 'Reilly \& Chatman; 1996: 157-200).

When organizations promote a certain set of values, like respect for people and high pay for good performance, they create motivation that influences employees' attitudes and behaviors. For instance, Peters and Waterman $(1982,65)$ found exemplary organizations gave priority to values on quality, service, the importance of people as individuals, and innovation that motivated employees to improve performance and increase their morale, satisfaction, and commitment. Sommer, Bae and Luthans (1996: 977992) found that employees who perceived greater warmth, supportiveness, assigned responsibility, and rewards in their organizations increased their organizational commitment. Sheridan (1992: 10361056) found that firms emphasizing interpersonal relationship values retained employees better than firms emphasizing work task values.

Organizational culture has traditionally been assessed by qualitative methods as interviews and observations (Smircich, 1983: 339-358). Qualitative research tools are preferable to quantitative instruments in helping researchers understand such manifest level elements of culture as artifacts and stories. However, observation and interviews may encourage employees to act different and respond to interview questions to look "socially desirable". Moreover, a participant observer may interpret observations subjectively. Quantitative methods, on the other hand, offer advantages for crosssectional organizational research and large-scale studies (Cooke \& Rousseau 1988, pp. 245-273). They enable culture researchers to replicate assessments of culture in different units and to readily compare data across studies. Quantitative instruments such as questionnaires are also less prone to social desirability bias than interviews.

\section{Individual/Employee Values}

Just like organizational culture, individual values can also be assessed by both qualitative and quantitative methods. For instance, one can assess personal values by observation or interview. According to Rokeach, drawing inferences about an individual's values from their behavior or interview responses is problematic because: interpreting and quantifying values is difficult; the observer's (or researcher's) own values may influence the assessment; and a person might not be willing or able to talk about his values, or might be selective in revealing them (Rokeach, 1973: 32).

Although qualitative methods such as using focus groups might be more appropriate for generating a list of values, once that list is developed quantitative instruments facilitate data collection and analysis, particularly the proposed comparisons of individual and organizational values. Researchers have utilized several quantitative instruments to measure individual values such as: the values and lifestyles system (VALS) (Mitchell, 1983) and the value survey (Schwartz, 1992).

Schwartz \& Bilsky constructed a three dimensional theory of universal value types utilizing the 56 item Schwartz Value Survey (SVS). The first dimension is the distinctiveness of individual value region, the second is motivational structure and the third is individual, collective \& mixed interests. Schwartz 
provides a visual aid to assist the reader in conceptualizing the distinctiveness of the individual value regions (Schwartz 1992, 25). Schwartz contends that the motivational structure is composed of the dynamic interaction between the individual value regions. Thus, each of the four identified higher order value types such as: self-transcendence, conservation, self-enhancement, and openness-to-change are a compilation of compatible individual value domains (Schwartz,1995: 88-107). He also identifies three broad dimensions of values based on his cross-national study: (1) autonomy versus embeddedness, (2) egalitarianism versus hierarchy and (3) harmony versus mastery.

In sum, Schwartz (1995) hypothesized that the dynamic relations between the pairs of the value types (e.g. compatible values) are based on the interests served by their attainment. For example, power, achievement, hedonism, stimulation, and self-direction are all values, which serve individual or self-interest, while those that serve collective or social interest are benevolence, tradition and conformity. According to Schwartz (1995) the construct has two-dimension structure (social and self-interest) that was composed of the four higher order motivational value types.

\section{Social Identity\&Impression Management Theories}

I have looked into organizational commitment and social identity theory to be able to understand corporate citizenship by linking them with the above theories. Social identity theory probes into membership within groups and organizations (Hogg and Abrams, 1988; Tajfel and Turner, 1979). The theory argues that people define themselves in part through the groups or organizations to which they belong. To the degree that people define themselves through a large group-based "social self", they use their assessments of how society views and treats the groups to which they belong and evaluate their own identities. This suggests that people will be concerned about issues of their status when evaluating their connection to an institution such as workplace.

White collar and or qualified job positions in financial institutions (hereafter referred as professional positions) define social identities in two ways. First, such working status provides categories defining the prototypical attributes associated with both organizational belonging and social identity that become the salient dimensions in people's social identities. Second, the status associated with the organization influences people's feelings of self-esteem and self-worth. It is mainly this latter one that is the focus of this paper. Identitybased theories argue that people use interactions with others as a source of information about their social identities and all the relevant decisions pertaining to their social identities. People use work groups to categorize themselves at work and the hierarchy or status of those groups and their positions in the organization to assess their worth (Tajfel \& Turner, $1979,1985 \& 1986)$.

One way that people form their social identities is through experiencing the way they are treated by other people, that is, by "reflected appraisals". This "looking glass" self is created through inferences and perceptions made about one's status based upon the quality of the treatment experienced when interacting with others. Social identity theory argues that people are influenced by their judgments of both by the status of the organization they work for and/or their work status of their organization relative to other organizations or the rest of the society at large for "positive distinctiveness" Although we do not focus on the "within" or "intragroup" dynamics" within their particular work institution and the specific dynamics, we argue that work institutions emphasize their search for dilemma of uniqueness from the other and sameness within their own group in general (Tajfel and Turner, 1986). I have emphasized role identification and value internalization to understand employees' orientations toward judgments about one's status and position both in and out of the organization of work. I suggest and hypothesize that 'the good corporate citizen' may align in congruence with the expected values of the organization and workgroups and commit himself or herself to work and organization through empowerment and trust.

I have operationalized our concepts with autonomous attitudes rather than comparative values concerning the major dimensions of social identity. That is, I framed our judgmental statements like " I am proud of working in my organization" rather than "My bank is better than other banks" so that no other reference point is given. Hence, I narrowed down our conception of social identity so that employees can focus on their internal values and self-categorization within the framework of their own organization rather than comparative assessment of social identity with other organizations. In this study, I have investigated this important issue and intended to extend our understanding of citizenship behavior with positive connotations rather than normative ones. I examined whether personal commitment values are related to 
Future research will benefit by collecting comparative and longitudinal data. Besides we have had difficulties in drawing a demarcation line between commitment to work and organization and had to incorporate commitment and social identity variables to our citizenship model. Despite the limitations, our study enhances our understanding of commitment and citizenship behaviors. Overall, the results suggest the importance of individual values and perceptions as well as pattern of interactions among colleagues at work. Additional research in this area seems critical to advancing our understanding of the relation between organizational commitment and citizenship behavior. I have just attempted to make a first cut assessment of the perceptions of employees on $\mathrm{CC}$ as the main internal stakeholder. The next step demands researchers to analyze the outcome of employee perceptions and attitudes on the company, its products and services along with customer perceptions. That way, the interactive relation between a company's reputation and stakeholders' perceptions about an organization's ability to enhance $\mathrm{CC}$ as a value creation and leverage for difference may be examined as well.

Finally, the 'universalistic' and 'indigenous' approaches represent two polar extremes in the so-called transferability debate. What is now emerging seems to be a resolution of this issue by a middle approach which incorporates universal organizational imperatives and generic variables with indigenous characteristics arising from specific situational context such as culture which need to be empirically researched. It is at the behavioral level, of course, that culture is most influential. Organizations in developing countries as in Turkey are often found to have a rational bureaucratic 'shell' within which the global cultural norms and corporate imperatives mentioned earlier operate. It remains to be seen whether such a hybrid approach will develop further or whether the transferability debate that emphasize both convergence and divergence will go on.

Similar to our findings, the transferability debate confirms that the employment relationships in developing countries will be subject to similar and perhaps exacerbated contradictory value shifts and universal cultural tendencies as are experienced in developed countries such as the gap between ideal human resource policies (usually based on Western norms of 'best practice') and actual practices is large. Thus, the employment relationships along with the human resource management display a distinct 'dualism' the formal contract and global norms on the one hand and the informal, culture infused, job behavior and employee perceptions on the other.
Perhaps, we will reach a consensus on the basics of corporate governance when these two sides of the coin are aligned, synchronized integrated better- be it in practice or in theory. Both corporate citizenship and organizational identification/commitment constructs will continue to be significant since all dimensions of performance of all stakeholders are increasingly important with ongoing global competition. Yet, the relation between them within the framework of both internal and external stakeholders needs to be further probed. 


\section{REFERENCES}

Angle, H. L., \& Perry, J. L. (1981), "An empirical assessment of organizational commitment and organizational effectiveness", Administrative Science Quarterly, 26, 1-12.

Allen, N. and J. Meyer (1990a), Organizational Socialization Tactics: A Longitudinal Analysis of Links to Newcomer's Commitment and Role Orientation. Academy of Management Journal, 33(48): 847-858.

Allen, N.J. \& Meyer, J.P. (1990b), The Measurement and Antecedents of Affective, Continuance and Normative Commitment to the Organization , Journal of Occupational Psychology, 63, 1-18

Alwin, D. F., \& Krosnick, J. A. (1985), The measurement of values in surveys: a comparison of ratings and rankings. Public Opinion Quarterly, 1985, 49(4).

Ashford, B. E., \& Mael, F. (1989), Social Identity Theory And The Organization. Academy of Management Review, 14(1), 20-39.

Barker, David, Loek Halman \& Astrid V. (1993), The European Values Study 1981-1990: Summary Report, Cook Foundation, London.

Balay, Refik, (2000), Örgütsel Bag̃lılık (Organizational Commitment), Ankara: Nobel.

Bateman, T.S. \& Organ. D. W. (1983), Job Satisfaction and the Good Soldier: The Relationship Between Affect and Employee Citizenship, Academy of Management Journal, Vol.26.2.

Bay, E. ve Küskü, Fatma, (2006), Sorumluluk mu, Karlılık mı?(Responsibility or Profitability?), paper presented at 14th National Organization \& Management Conference, Atatürk University Erzurum, May 25-27; 707-13.

BCG-TR (The Boston Consulting Group)( 2005), Türkiye Kurumsal Yönetim Haritası (Corporate Governance Map of Turkey), Istanbul: Corporate Governance Association of Turkey Publication.

Bondy K.Matten D., Moon J. (2004), The Adoption of Voluntary Codes of Conduct in MNCs: A ThreeCountry Comparative Study, Business And Society Review, 109: 4; 449-477.
Borman, Walter C. (2004), The Concept of Organizational Citizenship, American Psychological Society, 13:6; pp. 238-241.

Burgess, Steven M. and Mari Harris (1999), Social Identity in an Emerging Consumer Market: How You Do the Wash May Say a Lot About Who You Think You Are, Advances in Consumer Research, Vol. 26. Clifton, Rita and J. Simmons (2003), Brands and Branding. London: The Economist \& Profile Books.

Carroll, Archie B.(1998), The Four Faces Of Corporate Citizenship, Business \& Society Review, September 1, Issue 100/101.

Cooke, R.A.\& Rousseau, D M. (1988), Behavioral Norms And Expectations: A Quantitative Approach To The Assessment Of Organizational Culture, Group \& Organization Studies, 13(3).

Çetin, Münevver Ölçüm, (2004), Örgütsel Vatandaşlık Davranışı (Corporate Citizenship Behavior).

Istanbul:Nobel Pub.

Erdil, Oya \& Keskin, Halil, (2003), Güçlendirmeyle İş tatmini, İş Stresi ve Örgütsel Bag̃lılık arasındaki ilişkiler: Bir Alan Çalışması (The Linkage Between Empowerment, Job Satisfaction, Work Stress and Organizational Commitment), İstanbul Üniversitesi İşletme Fakültesi Dergisi, 32:1, 7-24.

Falk, R.(1993), The Making of Global Citizenship, in J. Brecher, J.B. Childs, and J. Cutler (eds.) Global Visions: Beyond the New World Order, Boston: South End Press, 39-50.

Finegan, J.E., (2000), The Impact of Person and Organizational Values on Organizational Commitment. Journal of Occupational and Organizational Psychology, 2000, 73(2).

Hall; E. T (1990), Understanding Cultural Difference. Yartmouth, ME: Intercultural Press.

Hofstede, Geert (1980), Culture's Consequences. International Differences in Work-Related Values, Sage, London.

Hofstede, G. (1984), Cultural relativity of the quality of life concept. Academy of Management Review, vol. 9 No. 3.

Hofstede, G.( 1991), Cultures \& Organizations: Software of the Mind. New York, NY: McGraw Hill. Hofstede, G., (1994), Cultures and Organizations. 
London: HarperCollins Publishers, 1994.

Hofstede, G., (1998), Attitudes, values and organizational culture: Disentangling the concepts. Organizational Studies, 19(3).

Hogg, Michael A. \& Deborah Terry (2000), Social Identity and Self-categorization Processes in Organizational Contexts, Academy of Management Review, 25 (1), 121-140.

Hogg, M.A., and Abrams, D.(1988), Social Identifications. N.Y.: Routledge.

Hugh J. Arnold, Daniel C. Feldman (1986), Organizational Behavior. New York, NY: McGrawHill.

Göregenli, M. (1997), Individualist-collectivist tendencies in a Turkish Sample, Journal of Crosscultural Psychology. 28 (6).

Keyman, Fuat \& İçduygu, Ahmet (eds.), (2005), Citizenship in a Global World: European Questions and Turkish Experiences. London: Routledge.

Kiliç, Selçuk and Yüksel, Müberra, (2006), Customer Attitude and User Behavior towards Automobile Brands, 11th International Conference on Corporate Marketing and Communications, Ljubliana.

Kotter, J. P. \& Heskett, J. L., (1992), Corporate culture and performance. New York, NY: Free Press.

Küskü, Fatma and Anna Zarkada-Fraser (2004), An Empirical Investigation of Corporate Citizenship in Australia and Turkey, British Journal Of Management. Vol. 15;pp, 57-72.

MacKenzie, S.B, Podsakoff \& Fetter (1993), The Impact of Organizational Citizenship Behavior on Evaluations of Sales Performance", Journal of Marketing, 31-3.

Maignan, I., \& Ferrell, O. C. (2001) Corporate citizenship as a marketing instrument, European Journal of Marketing, Vol. 35,; issues 3/4, pp. 457-484.

Matten, D \& Crane, A (2004), Business Ethics : A European Perspective, Oxford University Pres, Inc., New York, NY.

Matten, D. \& Crane, A. (2005), Corporate Citizenship: Toward an Extended Theoretical Conceptualization,
Academy of Management Review, Jan. Vol. 30, 1; 166-179.

McClelland, D. C. \& Burnham, D. H., (1976), Power is the great motivator. Harvard Business Review, $54(2)$

Meglino, B.M. \& Ravlin, E.C. (1998), Individual values in organizations: concepts, controversies, and research, Journal of Management, 1998, 24.

Peterson, Dane K.(2004) The Relationship between Perceptions of Corporate Citizenship and Organizational Commitment, Business \& Society, September, Vol. 43, No. 3. 296-319.

O'Reilly, C. A., \& Chatman, J. A.,(1996),Culture as social control: corporations, cults, and commitment Research in Organizational Behavior, 18.

Organ , D. \& Ryan K. (1995), A Meta-analytic Review of Attitudinal and Dispositional Predictors of Organizational Citizenship Behavior, Personnel Psychology, 48.

Peters, T. J., \& Waterman, R. H., (1982), In search of excellence: Lessons from America's best-run companies. New York, NY: Harper \& Row.

Posdakoff, Philip M. and Scott B. Mackenzie (1994), Organizational Citizenship Behaviors and Sales Unit Effectiveness, Journal of marketing Research. 31: 351363.

Rindova, Violina P., I. O Williamson and A. P. Petkova (2005), Being Good or Being Known, Academy of Management Journal. 48 (6): 1033-1049.

Rokeach, Milton (1968), Beliefs, Attitudes, and Values, Jossey-Bass, San Fransisco.

Rokeach, M. (1973), The nature of human values. New York: Free Press.

Rokeach, M. (1979),. Understanding Human Values: Individual and Societal. New York: Free Press.

Schein E.H, (1985) Organizational Culture and Leadership. San Francisco: Jossey Bass.

Schneider, B., \& Bowen, D. E. (1995). Winning the service game. Boston: Harvard Business School Press.

Schwartz S.H., Huismans S. (1995), Values Priorities 
and Religiosity in Four Western Religions. Social Psychology Quarterly, 58.

Schwartz, S. H. \& Bilsky, W. (1987), Toward a theory of the universal content and structure of values: Extensions and cross-cultural replications. Journal of Personality and Social Psychology, 58

Schwartz, S.H. (1994), Are there universal aspects in the structure and contents of human values? Journal of Social Issues, 50.

Schwartz, S.H. (1992). Universals in the Content and Structure of Values. Theoretical Advances and Empirical Tests in 20 Countries in Zanna, M. (ed) Advances in Experimental Social Psychology, Academic Press, San Diego, 1-65.

Schwartz, S.H. \& W. Bilsky (1987). Toward a Universal Psychological Structure of Values, Journal of Personality and Social Psychology, vol. 53, (3): 550-562.

Schwartz, S.H. \& W. Bilsky (1990). Toward a Theory of the Universal Content and Structure of Values, Journal of Personality and Social Psychology, vol. 58, 878-891.

Sennett, Richard. (2003). Respect in a World of Inequality. N.Y.: W.W. Norton \& Co. Sheridan, J. E.(1992), Organizational Culture and Employee Retention. Academy of Management Journal, 35 (5)

Smircich, L., (1983) Concepts of culture and organizational analysis. Administrative Science Quarterly, 1983, 28.

Soysal Nuhog̃lu, Yasemin, (1994). Limits of Citizenship:Migrants and Post national Membership in Europe. Chicago: University of Chicago Press.

Sommer, S. M., Bae, S. H., \& Luthans, F. (1996).Organizational commitment across cultures: the impact of antecedents on Korean employees. Human Relations, 49 (7).

Tajfel, H., and Turner, J.C.( 1979). An Integrative Theory of Intergroup Conflict. In W.G. Austin and S. Worchel (eds.), The Social Psychology of Intergroup Relations. Monterey, CA: Brooks \& Cole.

Tajfel, H., and Turner, J.C. (1986). The social identity theory of intergroup behavior, in S. Worchel (ed.),
The Psychology of Intergroup Relations. Chicago: Nelson Hall.

Tajfel, H., \& Turner, J. C. (1985). The social identity theory of group behavior, in H. Tajfel (ed.), Psychology of Intergroup relations (pp. 15-40) Cambridge, UK: Cambridge University Press.

Thoresen, V. (2003), The Consumer Citizenship Network. Hedmark University College, Norway.

Tyler, Tom R.(1998). Why people cooperate with organizations: An identity-based perspective, in Barry M. Staw and Robert Sutton (eds.). Research In Organizational Behavior. Greenwich, CT: JAI Press.

Valor,Carmen. (2005). Corporate Social Responsibility and Corporate Citizenship: Towards Corporate Accountability, Business and Society Review, 110:2; 191-212.

Windsor, D.(2001), Corporate Citizenship: Evolution And Interpretation in J. Andriof \& M. McIntosh(eds.), Perspectives On Corporate Citizenship: 39-52. Sheffield, UK: Greenleaf.

Willmott M.(2003), Citizen Brands: Corporate Citizenship, Trust and Branding, Journal of Brand Management, London: May 2003, Vol. 10, Issues 4/5.

Wood, D. J., \& Logsdon, J. M.(2001). "Theorizing Business Citizenship" in J. Andriof \& M. McIntosh (eds.), Perspectives on Corporate Citizenship: 83-103. Sheffield, UK: Greenleaf.

Yüksel, Müberra \& Sevgi Kalkan (2007), Employee Perceptions on Corporate Citizenship, 12th International Conference on Corporate Marketing and Communications, Middlesex University: London. 
APPENDIX

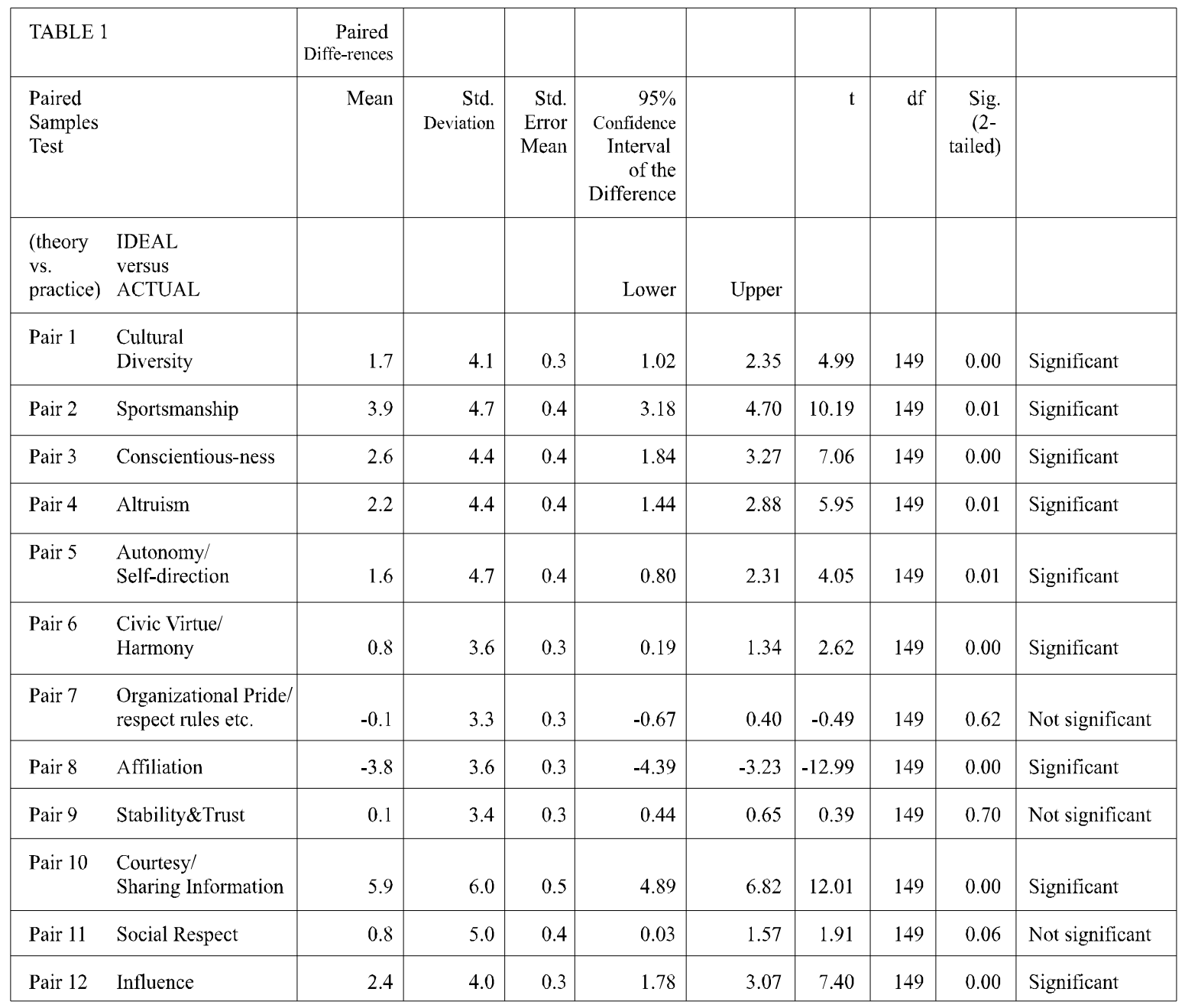

